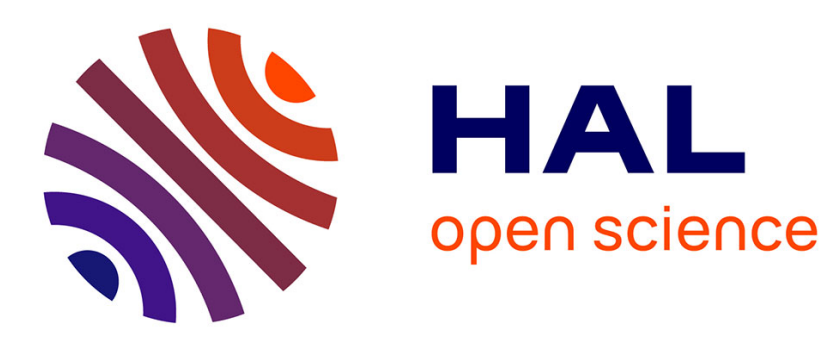

\title{
Investigation on internal electric field distribution of organic light-emitting diodes (OLEDs) with Eu2O3 buffer layer
}

Shengwei Shi, Dongge Ma

\section{- To cite this version:}

Shengwei Shi, Dongge Ma. Investigation on internal electric field distribution of organic light-emitting diodes (OLEDs) with Eu2O3 buffer layer. 2009. hal-00409393

\section{HAL Id: hal-00409393 \\ https://hal.science/hal-00409393}

Preprint submitted on 7 Aug 2009

HAL is a multi-disciplinary open access archive for the deposit and dissemination of scientific research documents, whether they are published or not. The documents may come from teaching and research institutions in France or abroad, or from public or private research centers.
L'archive ouverte pluridisciplinaire HAL, est destinée au dépôt et à la diffusion de documents scientifiques de niveau recherche, publiés ou non, émanant des établissements d'enseignement et de recherche français ou étrangers, des laboratoires publics ou privés. 
2

\title{
Investigation on internal electric field distribution of organic light-emitting diodes (OLEDs) with $\mathrm{Eu}_{2} \mathrm{O}_{3}$ buffer layer
}

\author{
Shengwei Shi*, Dongge Ma \\ State Key Laboratory of Polymer Chemistry and Physics, Changchun Institute of Applied Chemistry, Chinese Academy of Sciences, \\ 130022 Changchun, P. R. China
}

Received ZZZ, revised ZZZ, accepted ZZZ

Published online ZZZ (Dates will be provided by the publisher.)

PACS 73.40.Mr; 78.60.Fi, 81.15.Ef, 85.60.Jb, 85.60.Pg

* Corresponding author: e-mail hbhmfly@gmail.com, Phone: +33 38810 72 93, Fax: +33 388107249

We have found that organic light-emitting diode (OLED) performance was highly improved by using europium oxide $\left(\mathrm{Eu}_{2} \mathrm{O}_{3}\right)$ as a buffer layer on indium tin oxide (ITO) in OLEDs based on tris-(8-hydroxyquinoline) aluminium ( $\mathrm{Alq}_{3}$ ), which showed low turn-on voltage, high luminance, and high electroluminescent (EL) efficiency. The thickness of $\mathrm{Eu}_{2} \mathrm{O}_{3}$ generally was $0.5 \sim 1.5 \mathrm{~nm}$. We investigated the effects of $\mathrm{Eu}_{2} \mathrm{O}_{3}$ on internal electric field distributions in the device through the analysis of current-voltage characteristics, and

1. Introduction Since the first demonstration of OLEDs [1], a large research effort has focused on improving the device performance and understanding the device physics. Introduction of buffer layers at the interface between the electrode and organic active layer is indeed an efficient approach for OLEDs. On the one hand, a buffer layer inserted between the organic active layer and cathode can enhance electron injection and improve device performance [2-5]. On the other hand, many researches are focus on a buffer layer inserted between the anode and the organic active layer to control hole injection [6-10]. In general, the basic physical processes for OLEDs include injection, transport and recombination of charge carriers. To improve the device performance, a detailed understanding of the role that buffer layers in OLEDs on the charge carrier injection and transport processes is important.

Although LiF/Al is usually used as the cathode in OLEDs, and it is considered an effective way to improve the electroluminescence (EL) efficiency of devices [11], the injection of holes and electrons is still unbalanced [12]. In this letter, we investigate the effects of $\mathrm{Eu}_{2} \mathrm{O}_{3}$ as an efficient buffer layer on device performance and the internal found that the introduction of the buffer layer balanced the internal electric field distributions in hole transport layer (HTL) and electron transport layer (ETL), which should fully explain the role of the buffer layer in improving device performance. Our investigation demonstrates that the hole injection is Fowler-Nordheim (FN) tunnelling and the electron injection is Richardson-Schottky (RS) thermionic emission, which are very significant in understanding the operational mechanism and improving the performance of OLEDs.

Copyright line will be provided by the publisher

electric field distribution in the device, We have found that the introduction of the buffer layer balanced the internal electric field distributions in hole transport layer (HTL) and electron transport layer (ETL), leading to an improvement in the device performance. Our results show that the hole injection into NPB from anode is FN tunnelling and the electron injection into $\mathrm{Alq}_{3}$ from cathode is RS thermionic emission.

2. Experiments We have fabricated OLEDs with the following structure: ITO / $\mathrm{Eu}_{2} \mathrm{O}_{3}(0,0.5,1.0,1.5 \mathrm{~nm})$ / N,N'-bis(1-naphthyl)-N,N'-diphenyl-1,1` biphenyl -4,4`dimaine (NPB) $(50 \mathrm{~nm}) /$ tris-(8-hydroxyquinoline) aluminium $\left(\mathrm{Alq}_{3}\right)(60 \mathrm{~nm}) / \mathrm{LiF}(1 \mathrm{~nm}) / \mathrm{Al}(150 \mathrm{~nm})$. To investigate the internal electric field distribution of the device, we also fabricated two types of devices with different thickness of NPB $(20,40,60,80 \mathrm{~nm})$ for each one: A: ITO/NPB(x)/Alq $3(60 \mathrm{~nm}) / \mathrm{LiF}(1 \mathrm{~nm}) / \mathrm{Al}(150 \mathrm{~nm}) ; \quad \mathrm{B}$ : $\mathrm{ITO} / \mathrm{Eu}_{2} \mathrm{O}_{3}(1 \mathrm{~nm}) / \mathrm{NPB}(\mathrm{x}) / \mathrm{Alq}_{3}(60 \mathrm{~nm}) / \mathrm{LiF}(1 \mathrm{~nm}) / \mathrm{Al}(150 \mathrm{n}$ $\mathrm{m})$. The evaporation base pressure is at a vacuum of $5 \times 10^{-4}$ $\mathrm{Pa}$. The buffer layer $\mathrm{Eu}_{2} \mathrm{O}_{3}$ (deposition rate 0.04 0.06 $\mathrm{nm} / \mathrm{s}$ ) was deposited on the cleaned ITO glasses firstly, and 
the NPB was thermally evaporated (deposition rate 0.2 0.4 $\mathrm{nm} / \mathrm{s}$ ) as a hole transport layer. A 60-nm $\mathrm{Alq}_{3}$ film was evaporated at a rate $0.2 \sim 0.4 \mathrm{~nm} / \mathrm{s}$ as an electron transporting and light emitting layer. Then an electron injection layer (EIL) of thin $\mathrm{LiF}$ was deposited at a rate 0.04 0.06 $\mathrm{nm} / \mathrm{s}$ without breaking the vacuum. Finally, $150 \mathrm{~nm} \mathrm{Al}$ electrodes were deposited at a rate of $0.5 \sim 0.6 \mathrm{~nm} / \mathrm{s}$. The deposition rates were controlled by a quartz oscillating thickness monitor. The luminance-current-voltage characteristics were measured using a Keithley (2400 and 2000) source with a calibrated silicon photodiode. All measurements were performed at ambient atmosphere without encapsulation. The active area of the devices was $9 \mathrm{~mm}^{2}$.

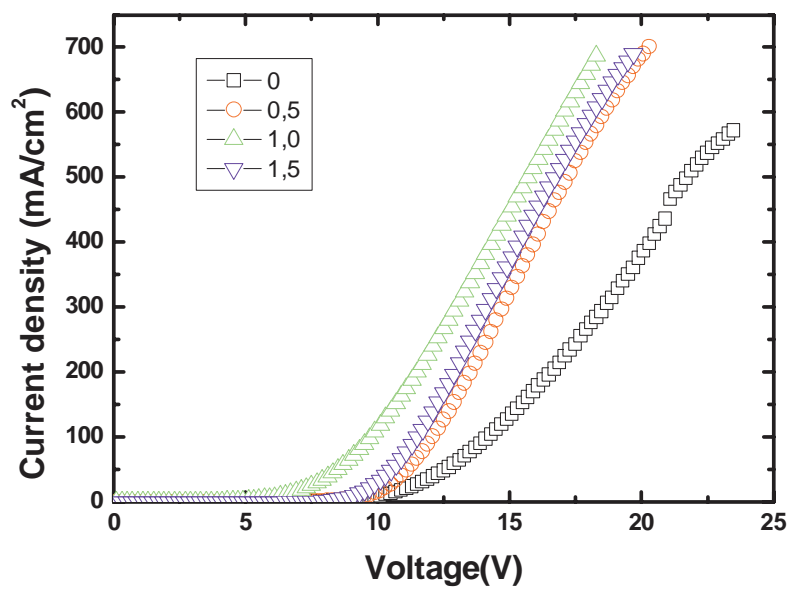

Figure 1 Current density-voltage characteristics of ITO/ $\mathrm{Eu}_{2} \mathrm{O}_{3}$ $(\mathrm{x} \mathrm{nm}) / \mathrm{NPB}(50 \mathrm{~nm}) / \mathrm{Alq}_{3}(60 \mathrm{~nm}) / \mathrm{LiF}(1 \mathrm{~nm}) / \mathrm{Al}(150 \mathrm{~nm})$ devices with different $\mathrm{Eu}_{2} \mathrm{O}_{3}$ thickness.

3. Experimental results The incorporation of a thin layer of $\mathrm{Eu}_{2} \mathrm{O}_{3}$ between ITO and NPB layer, and a thin layer of $\mathrm{LiF}$ between $\mathrm{Al}$ cathode and $\mathrm{Alq}_{3}$ layer, produced a significant improvement in the device performance. Fig. 1 shows the current density-voltage characteristic of devices with different thicknesses $(0,0.5,1.0,1.5 \mathrm{~nm})$ of the $\mathrm{Eu}_{2} \mathrm{O}_{3}$ buffer layer, including a reference device without $\mathrm{Eu}_{2} \mathrm{O}_{3}$. Compared with the reference device, the current at

Table 1 Device performance with varying thickness of $\mathrm{Eu}_{2} \mathrm{O}_{3}$.

\begin{tabular}{lllll}
\hline Thickness $(\mathrm{nm})$ & 0 & 0.5 & 1.0 & 1.5 \\
\hline Luminance $\left(\mathrm{cd} / \mathrm{m}^{2}\right)$ & 14260 & 21600 & 27994 & 22960 \\
Turn-on voltage $(\mathrm{V})$ & 5.5 & 4.7 & 3.5 & 4.9 \\
Current efficiency, CE, $(\mathrm{cd} / \mathrm{A})$ & 4.7 & 5.6 & 6.4 & 6.0 \\
Power efficiency, PE, $(\mathrm{lm} / \mathrm{w})$ & 1.9 & 2.7 & 3.1 & 2.4 \\
CE at $500 \mathrm{~mA} / \mathrm{cm}^{2}$ & 2.8 & 4.0 & 4.9 & 4.3 \\
PE at $500 \mathrm{~mA} / \mathrm{cm}^{2}$ & 0.4 & 0.7 & 1.0 & 0.8 \\
\hline
\end{tabular}

a certain voltage was enhanced upong introducing $\mathrm{Eu}_{2} \mathrm{O}_{3}$. For $\mathrm{Eu}_{2} \mathrm{O}_{3}$ thicknesses greater than $1.0 \mathrm{~nm}$, the current began to decrease. This means that the optimal $\mathrm{Eu}_{2} \mathrm{O}_{3}$ thickness is $1 \mathrm{~nm}$.

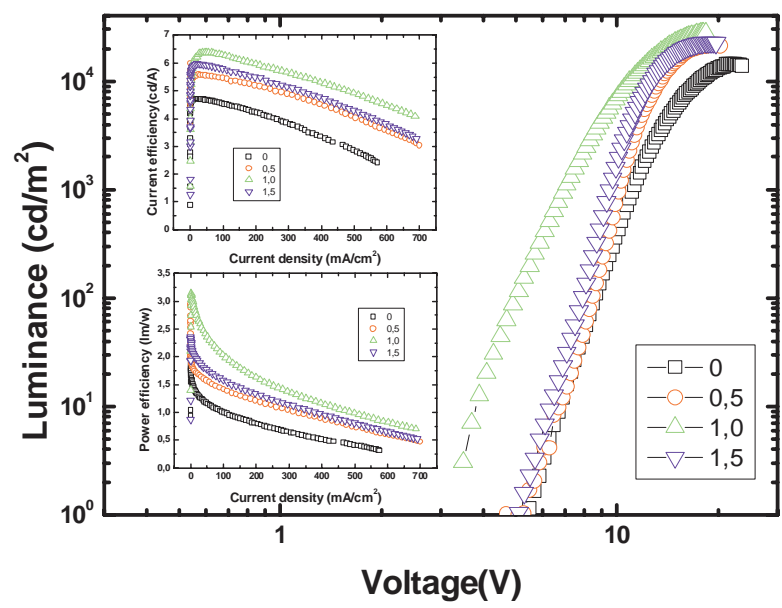

Figure 2 Luminance-voltage characteristics of ITO/ $\mathrm{Eu}_{2} \mathrm{O}_{3}$ (x $\mathrm{nm}) / \mathrm{NPB}(50 \mathrm{~nm}) / \mathrm{Alq}_{3}(60 \mathrm{~nm}) / \mathrm{LiF}(1 \mathrm{~nm}) / \mathrm{Al}(150 \mathrm{~nm})$ devices with different $\mathrm{Eu}_{2} \mathrm{O}_{3}$ thickness. Inserts: relations between current density and the current and power efficiencies.

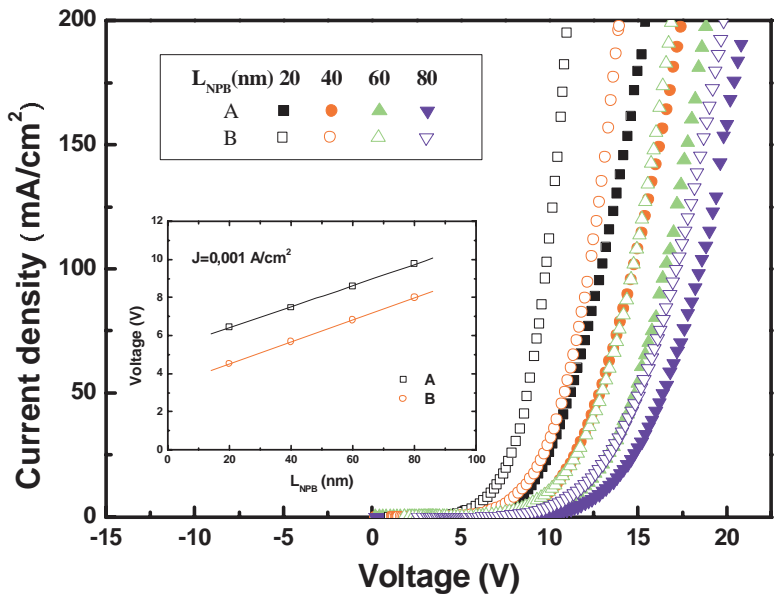

Figure 3 The total voltage drop on the diode is plotted against the thickness of NPB layer for the current density of 0.001 $\mathrm{A} / \mathrm{cm}^{2}$. Their slopes and intercepts are related to the average electric field in NPB and $\mathrm{Alq}_{3}$ layer, respectively. Insert: current density-voltage characteristics of device $\mathrm{A}$ and $\mathrm{B}$ with different thicknesses of NPB.

We present in Fig. 2 the bias voltage dependence of luminance. Upon introducing $\mathrm{Eu}_{2} \mathrm{O}_{3}$, the luminance is also 
greatly enhanced. Indeed, the luminance for $1.0 \mathrm{~nm} \mathrm{Eu}_{2} \mathrm{O}_{3}$ is nearly two times that of the reference device, while the turn-on voltage decreased from $5.5 \mathrm{~V}$ to $3.5 \mathrm{~V}$. The insert to Fig. 2 shows the relation between current efficiency, power efficiency with current density. Device efficiencies were also improved with the buffer layers. We present in Table 1 device performance as a function of $\mathrm{Eu}_{2} \mathrm{O}_{3}$ thickness in the range $0-1.5 \mathrm{~nm}$ that yields the best performance.

To elucidate the performance improvement of OLEDs with $\mathrm{Eu}_{2} \mathrm{O}_{3}$ buffer layer, we investigate the effects of buffer layers on average internal electric field distributions within the ETL and HTL in OLEDs, by studying steadystate $\mathrm{J}-\mathrm{V}$ characteristics $[12,13]$.

We first processed two types of devices $\mathrm{A}$ and $\mathrm{B}$ that either contain or do not contain the $\mathrm{Eu}_{2} \mathrm{O}_{3}$ buffer layer. For each type of device, we investigated four different thickness of NPB HTL, while keeping the thickness of $\mathrm{Alq}_{3}$ ETL fixed at $60 \mathrm{~nm}$. We present the J-V characteristics of these devices in Fig.3. For a given current density, the corresponding voltage values may thus be extracted from all J-V curves. The insert to Fig.3 presents the total voltage drop on the diode plotted against the thickness of the NPB layer for a current density of $0.001 \mathrm{~A} / \mathrm{cm}^{2}$. Obviously, the voltage drop exhibits a nice linear relation with the NPB layer thickness for every device, which indicates that the space charge effects in both HTL and ETL can be negligible at within certain current range.

Because of the large difference in the hole and electron mobilities in NPB and $\mathrm{Alq}_{3}[14,15]$, respectively, one expects that the $\mathrm{Alq}_{3}$ layer limits the current, implying that this layer takes on most of the voltage drop [16]. Indeed, the electroabsorption measurements by Rohlfing et al. have shown that the voltage drop at the $\mathrm{Alq}_{3}$ layer for positive bias is almost ten times larger than that at the NPB layer [17]. Thus, the voltage drop across the entire device occurs mostly across the $\mathrm{Alq}_{3}$ layer. Although $\mathrm{LiF}$ [18] and $\mathrm{Eu}_{2} \mathrm{O}_{3}$ [19] are wide band gap dielectrics, so that the voltage drops across them could be significant, this voltage drop is nevertheless negligible compared with the voltage drop across $\mathrm{Alq}_{3}$ layer. We may therefore approximate that the voltage drop across the devices occurs only across the HTL and ETL layers. In this case, the voltage (V) across the devices can then be written as $\mathrm{V}=\mathrm{V}_{\mathrm{HTL}}+\mathrm{V}_{\mathrm{ETL}}=\mathrm{F}_{\mathrm{HTL}}$ $\mathrm{L}_{\mathrm{HTL}}+\mathrm{F}_{\mathrm{ETL}} \mathrm{L}_{\mathrm{ETL}}$, where $\mathrm{F}_{\mathrm{HTL}}$ and $\mathrm{F}_{\mathrm{ETL}}$ represens the average electric field within HTL and ETL layers, respectively. We can then extract the average internal electric field distributions within the HTL and ETL from the slope and intercept of the linear relation at different values of current density $[12,13]$.

Although $\mathrm{LiF} / \mathrm{Al}$ is usually used as the efficient cathode in OLEDs, hole and electron injection is still unbalanced for the device [12]. For device A, the introduction of the $\mathrm{LiF}$ EIL enhances electron injection [1], so the internal electric field of HTL will be raised, although the internal electric field of ETL is reduced, the average internal electric field distributions in HTL and ETL are pulled away [12] (see Fig.4). Regarding device $\mathrm{B}$ containing the $\mathrm{Eu}_{2} \mathrm{O}_{3}$ buffer, the internal electric field in the HTL is reduced greatly compared with device $\mathrm{A}$, and the average internal electric field distributions in HTL and ETL become much more similar, which helps balance charge carrier injection and improve carrier recombination efficiency. The low resulting internal electric field in device B will also help to reduce the exciton quenching induced by the large internal electric field.

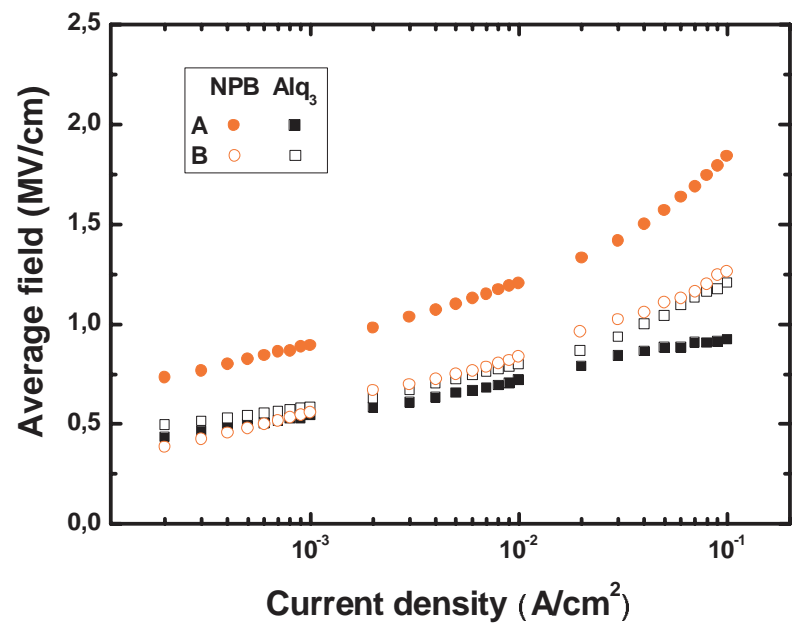

Figure 4 Average internal electric field distributions in NPB and $\mathrm{Alq}_{3}$ layers for devices $\mathrm{A}$ and $\mathrm{B}$.

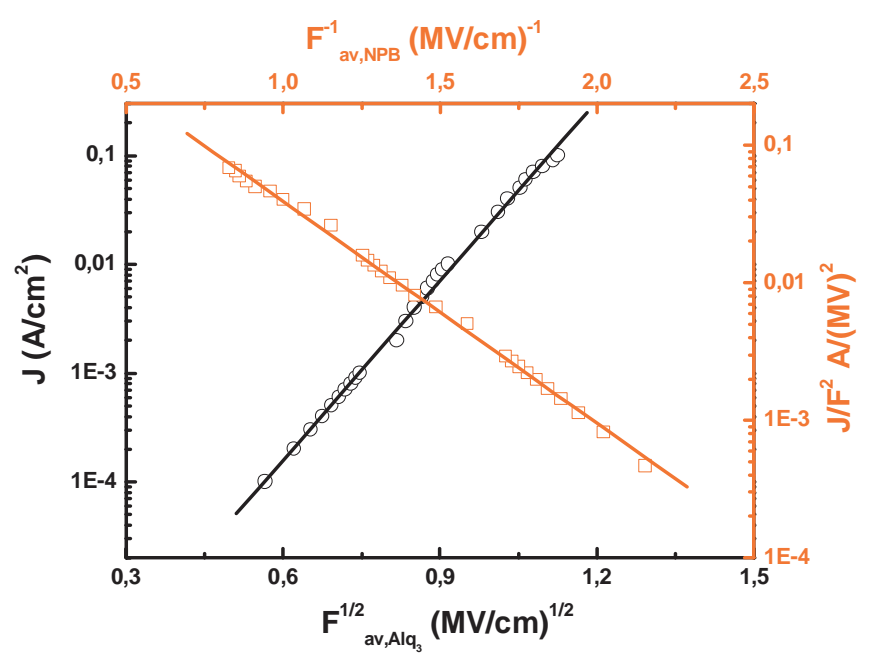

Figure 5 Dependence of the current density on the average internal electric field in NPB and $\mathrm{Alq}_{3}$ layers for device $\mathrm{B}$.

From Fig. 4, we can extract the dependencies of the total current density on the average electric field in HTL. For devices B, this dependence goes as $\log J / \mathrm{F}^{2}-\mathrm{F}^{-1}$ av, NPB plot, while the dependence of the total current density on the average internal electric field in ETL goes as $\log \mathrm{J}_{-}$ 
$\mathrm{F}^{1 / 2}$ av, Alq3 plot (Fig. 5) [12,13]. These dependencies imply that the hole injection into HTL is controlled by FowlerNordheim (FN) tunnelling, whereas the electron injection into ETL is controlled by Richardson-Schottky (RS) thermionic emission.

4. Conclusions In this work, we have introduced a thin film of $\mathrm{Eu}_{2} \mathrm{O}_{3}$ as an efficient hole injection layer into OLED heterostructures, which can greatly improve device electroluminescent performance. The optimal thickness of $\mathrm{Eu}_{2} \mathrm{O}_{3}$ was found to be $0.5 \sim 1.5 \mathrm{~nm}$. The peak luminance, current efficiency and power efficiency can reach 27994 $\mathrm{cd} / \mathrm{m}^{2}, 6.4 \mathrm{~cd} / \mathrm{A}$ and $3.1 \mathrm{~lm} / \mathrm{w}$, and the turn-on voltage can decrease from $5.5 \mathrm{~V}$ to $3.5 \mathrm{~V}$ compared with a reference device without the $\mathrm{Eu}_{2} \mathrm{O}_{3}$ buffer. Our experimental results clearly demonstrate that the hole injection from anode and the electron injection from cathode are FN tunnelling and RS thermionic emission, respectively. The introduction of both interfacial layers $\mathrm{Eu}_{2} \mathrm{O}_{3}$ and $\mathrm{LiF}$ not only lowers the average internal electric field inside the device, but also results in a balancing between the average internal electric field in the HTL and in ETL over the entire current range, which will help to balance charge carrier injection and improve device efficiency.

Acknowledgements We thank M. Bowen for a careful reading of the manuscript. D. Ma thanks the support of Hundreds Talents Program, Chinese Academy of Sciences and the National Science Fund for Distinguished Young Scholars of China (50325312).

\section{References}

[1] C. W. Tang and S.A. VanSlyke, Appl. Phys. Lett. 51, 913 (1987).

[2] Y. Luo, H. Aziz, G. Xu, and Z. D. Popovic, J. Appl. Phys. 101, 054512 (2007).

[3] J. Huang, G. Li, E. Wu, Q. Xu, and Y. Yang, Adv. Mater. 18, 114 (2006).

[4] S. Y. Chen, T. Y. Chu, J. F. Chen, C. Y. Su, and C. H. Chen, Appl. Phys. Lett. 89, 053518 (2006).

[5] X. D. Feng, C. J. Huang, V. Lui, R. S. Khangura, and Z. H. Lu, Appl. Phys. Lett. 86, 143511 (2005).

[6] S. A. Van Slyke, C. H. Chen, and C. W. Tang, Appl. Phys. Lett. 69, 2160 (1996).

[7] S. Y. Kim, J. M. Baik, H. K. Yu, and J. L. Lee, J. Appl. Phys. 98, 093707 (2005).

[8] C. A. Di, G. Yu, Y. Q. Liu, X. J. Xu, Y. B. Song, and D. B. Zhu, Appl. Phys. Lett. 89, 033502 (2006).

[9] J. Li, M. Yahiro, K. Ishida, H. Yamada, and K. Matsushige, Synthetic Met. 151, 141 (2005).

[10] C. C. Chang, M. T. Hsieh, J. F. Chen, S. W. Hwang, and C. H. Chen, Appl. Phys. Lett. 89, 253504 (2006).

[11] C. W. Tang, S. A. VanSlyke, and C. H. Chen J. Appl. Phys. 65, 3610 (1989).

[12] J. Chen and D. Ma, Chem. Phys. 325, 225 (2006).

[13] E. Tutis, D. Berner, and L. Zuppiroli, J. Appl. Phys. 93, 4594 (2003).
[14] R. G. Kepler, P. M. Beeson, S. J. Jacobs, R. A. Anderson, M. B. Sinclair, V. S. Valencia, and P. A. Cahill, Appl. Phys. Lett. 66, 3618 (1995).

[15] T. Tsutsui, H. Tokuhisa, and M. Era, Proc. SPIE 3281, 230 (1998).

[16] W. Riess, H. Riel, T. Beierlein, W. Brü tting, P. Mü ller, and P. F. Seidler, IBM J. RES. \& DEV. 45, 77 (2001)

[17] F. Rohlfing, T. Yamada, and T. Tsutsui, J. Appl. Phys. 86, 4978 (1999).

[18] T. Kurobori, T. Yamakage, Y. Hirose, K. Kawamura1, M. Hirano, and H. Hosono, Jpn. J. Appl. Phys. 44, 910 (2005).

[19] C. P. L. Rubinger, L. C. Costa, M. Macatrão, M. Peres, T. Monteiro, F. M. Costa, N. Franco, E. Alves, B. Z. Saggioro, M. R. B. Andreeta, and A. C. Hernandes, Appl. Phys. Lett. 92, 252904 (2008). 